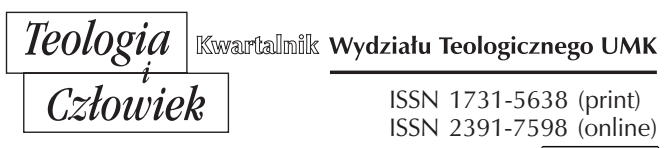

(ब) $(1)$

50(2020)2, ss. $301-316$

\title{
NAKOŻENIE RĄK W SAKRAMENTALNYCH OBRZĘDACH CHRZEŚCIJAŃSKIEGO WSCHODU. STUDIUM NA PRZYKŁADZIE PRAKTYKI W KOŚCIOŁACH SYRYJSKICH I BIZANTYJSKICH
}

DOI: http://dx.doi.org/10.12775/TiCz.2020.029

Streszczenie. Problematyka niniejszego studium oscyluje wokół niezwykle ważnego gestu sakramentalnego jakim jest nałożenie rąk, który choć wspólny całemu chrześcijaństwu, posiada różną formę i znaczenie w poszczególnych tradycjach liturgicznych. Kolejne części artykułu w syntetyczny sposób prezentują najpierw terminologię związana z tym gestem, a następnie praktykę i po części też teologię nałożenia rąk w celebracji misteriów (= sakramentów) Kościołów syryjskich i bizantyjskich. W pierwszej kolejności uwaga skupia się na sakramencie święceń, którego nazwa własna we wspólnotach chrześcijańskiego Wschodu nawiązuje właśnie do gestu włożenia rąk. Kolejny punkt dotyczy gestu włożenia rąk w chrześcijańskiej inicjacji. W ostatniej części znajdują się informacje dotyczące tych sakramentów Wschodu, w których gest nałożenia rąk jest obecny, choć nie należy do najważniejszych czynności liturgicznych.

Słowa kluczowe: liturgia; ręce; nałożenie rąk; sakramenty; święcenia; pokuta; inicjacja chrześcijańska.

Abstract. Imposition of Hands in the Sacramental Rites of the Christian East. Study based on the examples of practice of the Syriac and Byzantine Churches. The subject of the study concerns the most important sacramental gesture, i.e. the laying of 
hands. Even if it is common among all Christian Churches, it has a variety of functions and meanings throughout the different liturgical traditions. The successive parts of the article present, in a synthetic way, the terminology associated with this gesture, the liturgical practice and theology of the imposition of hands in the sacramental celebrations of the Syriac and Byzantine Churches. Firstly our attention focuses on the Sacrament of Holy Orders, which takes its proper name in the Christian East form the elaborated gesture. The next paragraph concerns the Christian initiation and the last one contains information about those sacraments of the East in which the gesture is present, even if it has not the same essential meaning.

Keywords: Liturgy, Hands, Lying of Hands, Holy Orders, Christian Initiation, Penance.

Nałożenie rąk należy do najważniejszych gestów sakramentalnych Kościoła wszystkich tradycji. Od najdawniejszych czasów posiadało ono głęboką symbolikę i wpisywało się w klasyczną definicję sakramentu: ten bowiem rozumiany jako widzialny znak niewidzialnej łaski, który sprawia to co oznacza, ukazywał nałożenie rąk jako szczególny akt epikletyczny, gest wskazujący na przyjęcie nowego członka wspólnoty czy też złączony z przekazaniem władzy gest wybrania i konsekracji ${ }^{1}$. Do dnia dzisiejszego gest ten jawi się jako jeden $\mathrm{z}$ najistotniejszych $\mathrm{w}$ czasie celebracji sakramentalnych. I chociaż należy on do depozytu całego Kościoła, to jednak różne tradycje w różny sposób wpisały go w obrzędowy charakter celebracji.

W niniejszym studium w syntetyczny sposób zaprezentowana zostanie najpierw terminologia związana $\mathrm{z}$ gestem a następnie krótko omówiona zostanie praktyka i teologia nałożenia rąk w celebracji poszczególnych misteriów Kościoła. Ponieważ w ramach syntetycznego studium nie sposób odnieść się do wszystkich tradycji liturgicznych, osią będą tu obrzędy zaliczane do liturgicznych tradycji syryjskich z odniesieniami do praktyk Kościołów bizantyjskich.

${ }^{1}$ B. Nadolski (oprac.), Leksykon liturgii, Poznań 2006, s. 1005-1006. 


\section{SYMBOLIKA I TERMINOLOGIA}

W jednym ze swoich artykułów Stratford Caldecott, w krótki i zarazem bardzo wyczerpujący sposób określił rolę rąk w życiu człowieka. Ów autor napisał m.in. takie słowa:

Ręce, jak wszystkie inne części ciała, są wyrazem duszy i przedłużeniem ludzkiego ducha, ale spełniają szczególną funkcję. Bardziej niż jakakolwiek inna część ciała, są na nasz rozkaz. Nimi dotykamy, otrzymujemy, bierzemy i tworzymy. [Ręce] odkrywają i wyrażają wolę. Możemy nimi czynić zarówno dobro jak i zło².

Nie może więc dziwić, że również w szeroko pojętej liturgii różnych kultur i tradycji, ręce stały się ważnym elementem celebracyjnym posiadającym głęboką symbolikę. By nie sięgać daleko wystarczy spojrzeć na tradycję Starego Testamentu, w której ręka wyraża m.in. błogosławieństwo (por. Rdz 48,14), przysięgę (por. Rdz 14,22), a także modlitwę i adorację (por. Ps 28,2$)^{3}$. Ponadto już w czasach przedchrześcijańskich rozwinął się sam obrzęd włożenia rąk, który był znakiem wspomnianego już błogosławieństwa, przekazania mocy i władzy (por. Lb 27,19); ów gest włożenia rąk mógł również wyrażać przeniesienie grzechu (por. Kpł 16,21), a czasem także przeznaczenie na śmierć przez ukamienowanie (por. Kpł 24,14)4. Metaforycznie mianem ręki określa się Bożą opatrzność, ale i opiekę. Lewa ręka Boga to sprawiedliwość, zaś prawa wyraża Jego miłosierdzie ${ }^{5}$.

Bez zagłębiania się w szczegóły należy stwierdzić, że również w chrześcijańskim języku teologicznym owa symbolika obecna jest od najdawniejszych czasów. Znaczenie prawicy i lewicy jest bardzo ważne w teologii i liturgii Kościołów wschodnich, zwłaszcza tradycji syryjskich,

2 S. Caldecott, Divine Touch: The Laying on Hands, "Communio" 38 (2011), s. 433.

${ }^{3}$ Por. A. Ridouard, Ramię i ręka, w: Słownik teologii biblijnej, red. X. Leon-Dufour (red.), Poznań-Warszawa 1973, s. 852-853.

${ }^{4}$ Por. M. Wojciechowski, Język gestów w Starym Testamencie, RBL 41 (1988) nr 6, s. 507-508.

${ }^{5}$ B. Nadolski, Leksykon symboli liturgicznych, Kraków 2012, s. 270-271. 
gdzie często się sięga do tego obrazu dla rozróżnienia między rzeczywistością pozytywną i negatywną (por. Mt 25,31-46). Należy pamiętać, że ów gest - podobnie jak w świecie judaistycznym - również u chrześcijan posiadał szereg innych znaczeń i także tu mógł wyrażać błogosławieństwo, przekazanie mocy czy też potwierdzenie wyboru' ${ }^{6}$. Oczywistym jest jednak, że już w najwcześniejszym okresie chrześcijańskim stanowił on podstawowy element obrzędowy wielu misteriów i rozumiany był jako przekazanie Ducha Świętego ${ }^{7}$ i tak też najczęściej jest rozumiany we wszystkich Kościołach apostolskich. Stąd też we wspólnotach chrześcijańskiego Wschodu gest nałożenia rąk w sakramentalnym obrzędzie posiada zasadniczo tę samą co w Kościele łacińskim symbolikę i znaczenie teologiczne.

Należy jednak zauważyć, że tradycje wschodnie rozróżniają dwa rodzaje gestu liturgicznego włożenia czy też nałożenia rąk, stąd też koniecznym jawi się tu jasne doprecyzowanie pojęć, gdyż to od nich zależy teologiczne rozumienie różnych form omawianego gestu. Jeśli chodzi o owo wschodnie rozróżnienie włożenia rąk (czy lepiej: ręki w liczbie pojedynczej) to na płaszczyźnie epistemologicznej wyglądają one jednakowo. Różnica leży tu w interpretacji istotowej, z którą związana jest cała idąca za owymi gestami teologia. Kościoły wschodnie posługują się tu dwoma ważnymi terminami zaczerpniętymi z greki: chirotonía

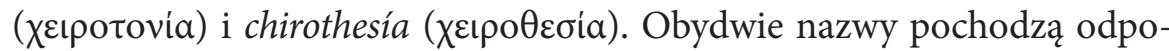

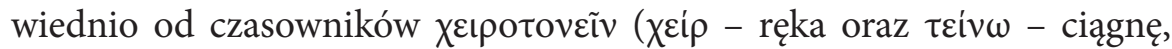
wyciągam, głosuję) wyciągnąć ręce i $\chi \varepsilon ı \rho \theta \varepsilon \tau \varepsilon \tilde{v}$ ( $\chi \varepsilon i \rho$ oraz $\tau i \theta \eta \mu \iota^{8}-$ kładę, umieszczam) - położyć ręce. W historycznym znaczeniu słowo chirotonía oznaczało głosowanie przez podniesienie ręki, swoistego rodzaju wybór

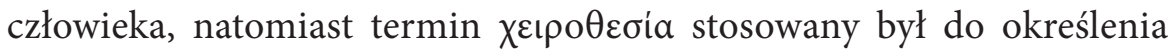
właśnie aktu nałożenia $r_{2} k^{9}$.

${ }^{6}$ T. Mannooramparampil, Holy Orders and Priesthood in the Syro-Malabar Church, w: Syriac Dialogue. Sixth Non-Official Consultation on Dialogue within the Syriac Tradition, red. P. Hofrichter, G. Wilflinger, Pro Oriente 6, Vienna 2004, s. 121.

7 G. Diekmann, The Laying On of Hands: the Basic Sacramental Rite, "CTSA Proceeding" 29 (1974), s. 339.

8 Znaczenie słów greckich zob. R. Romizi, Vocabolario greco-italiano etimologico e ragionato, Bologna 2012.

9 Zob. P. Nowakowski, Liturgiczna eklezjologia sakramentu kapłaństwa w obrządku wschodnim, RBL 63 (2010) nr 2, s. 128-129. 
Autorzy omawiający to zagadnienie zauważają, że początkowo obydwa terminy używane były zamiennie, głównie na określenie święceń wszelkich stopni. Mimo tego już od wczesnych wieków zauważamy kształtującą się tu pewną różnicę. W dokumentacji wczesnochrześcijańskich synodów oraz w pismach patrystycznych chirothesía rozumiana była bowiem nie tylko jako akt przekazania sukcesji, ale również jako właściwy moment wyboru biskupa. Z kolei słowo chirotonía chętniej odnoszono do czynności związanych z konsekracją lub wyniesieniem do stanu kapłańskiego. Ostatecznie jednak dopiero od VIII wieku prawne i liturgiczne dokumenty Kościołów bizantyjskich zaczęły w jasny sposób stosować rozróżnienie. I tak słowem chirotonía zaczęto określać obrzędy święceń biskupa, prezbitera i diakona, zaś termin chirothesía został związany ze święceniami niższymi czy szczególnymi posługami w Kościele (w tradycjach wschodnich włożenie ręki ma miejsce zasadniczo przy udzielaniu wszystkich posług liturgicznych $)^{10}$.

Należy jednak zauważyć, że chociaż przywołane tu terminy w ciągu wieków zaczęto odnosić głównie do celebracji związanych z misterium święceń, to jednak włożenie rąk czy też ręki związane jest również z celebracją innych sakramentów. Wydaje się więc, że na potrzeby niniejszego studium obydwa terminy możemy potraktować nie tylko jako nazwy własne obrzędów związanych $\mathrm{z}$ udzielaniem święceń, ale jako terminy techniczne odniesione również do pozostałych misteriów Kościołów chrześcijańskiego Orientu.

\section{WŁOŻENIE RĘKI W SAKRAMENCIE ŚWIĘCEŃ}

Logicznie rzecz ujmując prezentację gestu nałożenia rąk we wspólnotach Kościołów syryjskich wypada rozpocząć od sakramentu święceń. Nie chodzi tu bynajmniej o klerykalizację problemu. Na taką kolejność wpływają głównie dwa faktory. Po pierwsze w wielu wspólnotach chrześcijańskiego Wschodu sakrament święceń wymieniany jest na początku

${ }^{10}$ I. Cozma, The Holy Sacrament of Ordination - Principles and Elements of Canonical Doctrine, http://tto.ro/altarul-reintregirii/wp-content/uploads/2018/07/2.-IoanCozma-33-55.pdf (dostęp: 20.10.2018), s. 33nn. 
katalogu wszystkich misteriów Kościoła i - jak w przypadku Ojców i pisarzy syro-orientalnych - nazywany jest podstawowym sakramentem. Takie podejście wynika z faktu, iż orientalna intuicja chrześcijańska właśnie w kapłaństwie urzędowym widzi uzdolnienie do ważnego i godziwego sprawowania wszystkich innych sakramentów włącznie z chrztem i małżeństwem ${ }^{11}$. Drugim faktorem przemawiającym za postawieniem w punkcie wyjścia tego właśnie sakramentu jest wspomniana wyżej nomenklatura: w powszechnym rozumieniu Kościołów, zwłaszcza tradycji bizantyjskiej, chirotonía (rukopolojénié) i chirothesía (rukovozlojénié) odnoszą się głównie do posług znanych jako wyższe i niższe święcenia. Warto już w tym miejscu dodać, że w kontekście święceń chirotonía zazwyczaj odbywa się w czasie sprawowania liturgii eucharystycznej (wyjątek stanowi tu tradycja syro-orientalna) oraz w przestrzeni sanktuarium, tuż przed ołtarzem. Z kolei chirothesía sprawowana jest poza Eucharystią, najczęściej przy tronie biskupim bądź na stopniu przed ikonostasem lub zasłoną sanktuarium ${ }^{12}$. Badając najstarsze podania dotyczące obrzędów święceń (np. Konstytucje Apostolskie) zauważamy, że włożenie rąk na głowę kandydata do święceń wszystkich szczebli było zwyczajną praktyką Kościoła pierwotnego. Jeden z największych reformatorów liturgii Asyryjskiego Kościoła Wschodu, patriarcha Isho'yahb III ( $†$ 658), podkreśla, że to właśnie przez nałożenie rąk od czasów apostolskich przekazywane jest kapłaństwo ${ }^{13}$. Podobnie zresztą wypowiadali się inni wielcy teolodzy wschodni, a tradycja syro-orientalna do dziś utrzymuje nawet, że sam Jezus nie tylko przyniósł chrześcijańskie funkcje kapłańskie, ale ustanowił je właśnie przez włożenie rąk. Stąd w Asyryjskim Kościele Wschodu gestu nałożenia rąk używa się przy wszystkich stopniach święceń poza ustanowieniem korepiskopa i archidiakona ${ }^{14}$.

Gest włożenia prawej ręki biskupa (w większości tradycji jest to zwyczajna forma stosowana przy udzielaniu święceń), zazwyczaj poprzedza modlitwę konsekracyjną. Zgodnie ze starożytną tradycją rękę na głowę kandydata wkłada jedynie główny celebrans. Dotyczy to zarówno

${ }^{11}$ M.R. Potoczny, Święcenia prezbiteratu w Kościołach syryjskich. Historia i struktura obrzędu, „Roczniki Teologiczne” 65 (2018) nr 8, s. 129-130.

12 N. Bux, M. Loconsole, I misteri degli Orientali, Siena 2006, s. 98.

${ }^{13}$ Isho'yahb III, Liber Epistularum, CSCOSyr 64, Parisiis 1904, s. 201.

14 Zob. T. Mannooramparampil, Holy Orders, s. 121. 
święceń niższych jak i święceń diakonów, prezbiterów i - w większości obrządków - biskupów. Tak więc w przypadku święceń prezbiteratu nie mamy do czynienia z gestem włożenia rąk całego obecnego prezbiterium, jak to jest w przypadku tradycji Kościoła łacińskiego. Podczas święceń episkopatu w Kościołach syro-orientalnych zdarza się jednak, że współkoncelebrujący biskupi wkładają swoje prawe ręce na głowę kandydata wraz z celebransem głównym. W świadectwach tej samej tradycji liturgicznej znajdujemy jeszcze inną ciekawą wzmiankę dotyczącą święceń katolikosa w patriarchacie Seleucji-Ktezyfonu. Informuje nas ona o kolektywnym geście włożenia rąk, jednakże tylko celebrans główny czyni ten gest na głowie kandydata, z kolei obecni metropolici kładą swoje prawe dłonie na ciele święconego, natomiast pozostali biskupi wyciągają jedynie prawą rękę w jego stronę ${ }^{15}$.

W Kościołach tradycji zachodniosyryjskiej gest nałożenia rąk na głowę przyszłego prezbitera jest ściśle związany z konsekrowanymi postaciami eucharystycznymi. Stąd też sam obrzęd ma miejsce pod koniec anafory eucharystycznej ${ }^{16}$. We wspólnotach należących do tej tradycji w trakcie święceń prezbiteratu biskup, przed włożeniem rąk na głowę kandydata, wyciąga je nad konsekrowanymi postaciami, „zagarnia” dosłownie łaskę z nich emanującą i niejako przenosi ją na głowę świeconego. W tym czasie swymi dłońmi imituje ruch gołębich skrzydeł, co $\mathrm{w}$ tradycji syryjskiej ma wyraźne odniesienie epikletyczne (podobny gest przewidziany jest w momencie epiklezy nad darami w czasie modlitwy eucharystycznej). Plastyczność tego gestu ma przyczynić się do wzmocnienia wiary wspólnoty i sprawić niemal namacalnym działanie Ducha Świętego, który w tym właśnie momencie czyni z człowieka prawdziwego pneumatofora ${ }^{17}$. Warto zauważyć, że $\mathrm{w}$ tradycji zachodniosyryjskiej w czasie święceń nie używa się oleju, gdyż namaszczenie zastąpione jest właśnie nałożeniem $\mathrm{rąk}^{18}$.

${ }^{15}$ P. Jounel, Le ordinazioni, w: La Chiesa in preghiera, t. 3, I Sacramenti, red. A. Martimort, Brescia 2002, s. 169.

16 Por. M. Nin, La liturgia dell'Ordine nella tradizione Siro-Occidentale (dispense per gli studenti), Roma 2012, s. 9.

${ }_{17}$ M.R. Potoczny, Święcenia, s. 137.

${ }^{18}$ K.M. George, Sacrament of Ordination in the Malankara Orthodox-Syrian Church, w: Syriac Dialogue, s. 86. 
W najbliższej nam geograficznie tradycji bizantyjskiej święcenia episkopatu następują w czasie pierwszej części liturgii eucharystycznej po Małym Wejściu. Po odśpiewaniu Trishagionu, kandydat podchodzi do ołtarza, klęka przed nim opierając swoją głowę o mensę. Następnie diakoni rozkładają księgę Ewangelii nad głową święconego, zaś celebrans główny wkłada na niego prawą rękę. Ów gest nie dokonuje się w ciszy, tak jak ma to miejsce w Kościele łacińskim: celebrans odczytuje bowiem najpierw bullę potwierdzającą wybór na biskupa, a następnie odmawia w ciszy modlitwę prosząc o dary Ducha Świętego potrzebne przyszłemu biskupowi. Po zakończeniu modlitwy, biskup nadal trzyma rękę na głowie kandydata, zaś jeden z współkonsekratorów w ciszy odmawia krótką modlitwę litanijną, po której główny celebrans odmawia drugą modlitwę za święconego ${ }^{19}$.

W przypadku sakramentu święceń w tradycji bizantyjskiej już sama wspomniana wyżej nomenklatura wskazuje na główny element jego administracji i właściwie już w nazwie nawiązuje się tu do omawianego w niniejszym studium gestu: chirotonía (rukopolojénié) i chirothesía (rukovozlojénié). W przypadku tzw. święceń wyższych gest włożenia ręki na głowę kandydata jest jednym z pierwszych elementów obrzędu święceń, kiedy to biskup wkłada na głowę kandydata prawą rękę odmawiając starożytną formułę modlitewną 'H $\theta$ cía xápıs (którą zresztą spotykamy również $\mathrm{w}$ innych tradycjach Orientu ${ }^{20}$. Chociaż modlitwa ta posiada charakter epikletyczny to jednak większość badaczy uważa, że nie jest to inwokacja do Ducha Świętego, a jedynie proklamacja tego, co za chwilę ma się wydarzyć bądź też akt wyboru kandydata wyrażony przez wspólnotę Kościoła ${ }^{21}$. Z kolei drugie i trzecie nałożenie prawej ręki (nie obu, jak w przypadku liturgicznej tradycji łacińskiej) połączone są z modlitwami konsekracyjnymi, i tu gest ten ma już wyraźne znaczenie epikletyczne; gest włożonej ręki trwa tak długo, jak długo odmawiane są ciche modlitwy

${ }_{19}$ N. Bux, M. Loconsole, I misteri, s. 101. Por. P. Jounel, Le ordinazio$n i, 171-172$.

${ }^{20}$ L'Eucologio Barberini gr. 336, red. S. Parenti, E. Velkovska, Roma $2000^{2}$, s. 165. Tłum. polskie: „Łaska Boża, która zawsze uzdrawia to co chore i uzupełnia braki, niech uczyni prezbiterem diakona $N$. Módlmy się więc, aby zstąpiła na niego łaska Ducha Świętego".

${ }^{21}$ Por. M.R. Potoczny, Święcenia, s. 133-134. 
konsekracyjne. Należy dodać, że tradycja bizantyjska nie zna „współ-włożenia” rąk kolegium biskupiego (w przypadku święceń biskupich) bądź zgromadzonego prezbiterium (w przypadku święceń prezbiteratu) ${ }^{22}$.

W przypadku tzw. święceń niższych subdiakonatu biskup wkłada ręce na głowę kandydata na początku obrzędu i odmawia modlitwę, która jednak nie ma charakteru epiklezy. Z kolei w obrzędzie ustanowienia lektora i kantora liturgia przewiduje dwukrotne włożenie ręki: pierwsze poprzedza obrzęd tonsury zaś drugie następuje w momencie odmawiania właściwej modlitwy ustanowienia ${ }^{23}$.

\section{NAłOŻENIE RĄK W SAKRAMENTACH INICJACJI CHRZEŚCIJAŃSKIEJ}

Kolejnym momentem sakramentalnym, w którym nałożenie rąk jawi się jako jeden $\mathrm{z}$ najistotniejszych gestów liturgicznych jest chrzest św. i szerzej - cała chrześcijańska inicjacja. Ów gest należy tu bowiem do trzech szczególnych znaków wskazujących na kanały działania łaski Ducha Świętego. Sebastian Brock zauważa, że dla wschodnich Ojców Kościoła Duch Święty udzielany jest w wodzie chrzcielnej, ale zawsze w łączności z gestem włożenia rąk na głowę kandydata ${ }^{24}$. Didascalia apostolorum w tym szczególnym geście widzą swoisty moment wybrania człowieka: w myśl tego starożytnego przekazu przez nałożenie rąk biskupa w momencie chrztu sam Pan o każdym składa świadectwo i wypowiada słowa „Ty jesteś moim synem, Jam cię dziś zrodził” (por. Ps 2,7; Hbr 5,5)25. Warto również zauważyć, że w tradycjach chrześcijańskich wspólnot syryjskich nałożenie rąk w obrzędach inicjacji było czasem zastępowane namaszczeniem, gdyż obydwu obrzędom przypisywano to samo znaczenie ${ }^{26}$.

${ }^{22}$ Zob. S. Rosso, La celebrazione della storia della salvezza nel rito bizantino. Misteri sacramentali, feste e tempi liturgici, Città del Vaticano 2010, s. 460-451. Por. N. Bux, M. Loconsole, I misteri, s. 102-104.

${ }^{23}$ Zob. P. Jounel, Le ordinazioni, s. 170.

${ }^{24}$ Por. S.P. Brock, The Holy Spirit in the Syrian Baptismal Tradition, Piscataway 2008.s. 52 .

${ }^{25}$ The Didascalia Apostolorum in Syriac, t. I, red. A. Vööbus, (CSCO 401, Syr. 175), Louvain 1979, s. 109. Por. M.R. Potoczny, Misterium chrzcielne w Asyryjskim Kościele Wschodu, Opole 2019, s. 111.

${ }^{26}$ M. Pomazansky, Orthodox Dogmatic Theology, Platina 1984, s. 270-277. 
W niektórych orientalnych wspólnotach chrześcijańskich pierwsze nałożenie rąk wiązało się z przyjęciem do katechumenatu, jednakże nie była to praktyka jednolita. Modlitwa towarzysząca obrzędowi była prośbą o oświecenie i umocnienie kandydata na drodze wiodącej do chrztu ${ }^{27}$. Ponadto należy wspomnieć, że pierwotne Kościoły syryjskie nie znały ani namaszczenia, ani włożenia rąk po chrzcie. Po obmyciu chrzcielnym neofita po prostu uczestniczył w ofierze eucharystycznej ${ }^{28}$.

Jeśli chodzi o samą celebrację sakramentu to w tradycji syro-orientalnej pierwsze nałożenie ręki następuje bezpośrednio po modlitwach wprowadzających. Rubryka wprowadzająca brzmi następująco: „I [kapłan] powtarza głosem słyszalnym tę [modlitwę] nałożenia rąk [syr. syamidā], kładąc rękę na głowie każdego z nich [kandydatów] ${ }^{29 "}$. Ciekawym jest fakt, że modlitwa towarzysząca gestowi nałożenia ręki nie posiada charakteru epikletycznego; z kolei sama rubryka nie precyzuje również którą rękę wkłada kapłan na głowę kandydata. Te dwa szczegóły mogą sugerować, że gest nałożenia ręki ma tu jedynie znaczenie wyboru kandydata do chrztu przez wspólnotę Kościoła.

Kolejna wzmianka o nałożeniu ręki występuje w momencie samego chrztu. W obrzędach czytamy: „zanurza on [kapłan] dziecko w wodzie po szyję i kładzie swą rękę na jego głowie i zanurza ją w wodzie"30.

Bezpośrednio po chrzcie i włożeniu szat akcja liturgiczna przenosi się przed sanktuarium świątyni. Tu kapłan odmawia kolejne syamidā, zaś rubryka wprowadzająca precyzuje, że w trakcie modlitwy kapłan wkłada prawą rękę kolejno na wszystkich nowoochrzczonych. W samej modlitwie jest mowa o udzielonym już w obmyciu chrzcielnym Duchu Świętym ${ }^{31}$.

Należy zauważyć, że w niektórych wspólnotach zachodniosyryjskich nałożenie rąk na głowę kandydata do chrztu wiązało się $\mathrm{z}$ egzorcyzmem. W jednej z przewidzianych na ten moment modlitw czytamy:

27 I.-H. Dalmais, Le liturgie orientali, Roma 1982, s. 75.

${ }^{28}$ R. Cabié, L'iniziazione Cristiana, w: La Chiesa in preghiera, t. 3, red. A. Martimort, s. 75. Zob. M.R. Potoczny, Misterium, s. 99.

29 Tamże, s. 231. Zob. The Order of Baptism, Urmi 1890, s. 63. Por. S.P. Brock, The Holy Spirit, s. 53.

${ }^{30}$ M.R. Potoczny, Misterium, s. 250; The Order of Baptism, s. 77.

${ }^{31}$ M.R. Potoczny, Misterium, s. 252-253. 
wzywamy Twego Imienia [...] przeciw nieczystym duchom i - jak kładziemy ręce na tym Twoim stworzeniu i znaczymy go w imię Ojca i Syna i Ducha Świętego, przestrzegamy każdego przewrotnego, nieczystego i zbuntowanego ducha [...] aby uciekł i wyprowadził się z Twego stworzenia i Twego obrazu, dzieła Twoich rąk ${ }^{32}$.

Podobnie ja w innych wspólnotach apostolskich, również w Kościołach syryjskich nałożenie rąk oraz namaszczenie olejem łączy się ze szczególnym udzieleniem daru Ducha Świętego. Nie można tu jednak ulegać zachodniemu punktowi widzenia - omawiane wspólnoty mają tu zupełnie inną wizję niż Kościół łaciński i błędnym jest stosowanie tu zachodniego klucza polegającego na rozdziale misterium chrzcielnego na chrzest i bierzmowanie ${ }^{33}$.

Liturgia chrzcielna w tradycji bizantyjskiej również przewiduje moment włożenia rąk na głowę kandydata: ma to miejsce na początku celebracji tzw. „drugiego katechumenatu”, który jest bezpośrednim przygotowaniem do właściwego obrzędu oświecenia chrzcielnego. Bezpośrednio po naznaczeniu znakiem krzyża czoła, ust i piersi kandydata kapłan wkłada rękę na jego głowę. Ten gest, podobnie jak u Syryjczyków, bezpośrednio poprzedza egzorcyzmy ${ }^{34}$. Liturgie bizantyjskie, wyłączając niektóre wspólnoty unickie, zasadniczo nie przewidują nałożenia rąk po chrzcie. Stefano Rosso wyjaśnia ów fakt różnicą podejść teologicznych, które ostatecznie wpłynęły na takie ukształtowanie się praktyki ${ }^{35}$.

\section{NAŁOŻENIE RĄK W POZOSTAŁYCH SAKRAMENTACH KOŚClOŁÓW WSCHODNICH}

\subsection{NAMASZCZENIE CHORYCH}

Kolejnym misterium, który we wszystkich tradycjach liturgicznych wiąże się z gestem nałożenia rąk jest sakrament chorych. Najogólniej rzecz ujmując w przypadku sakramentu chorych ów gest interpretuje się

${ }^{32}$ S. Brock, The Holy Spirit, s. 56.

${ }^{33}$ M.R. Potoczny, Misterium, s. 114.

${ }^{34}$ S. Rosso, La celebrazione, s. 80nn.

35 Tamże, s. 100. 
głownie jako pocieszenie, nie posiada on więc wymiaru epikletycznego $^{36}$. Zanim zaprezentujemy krótko moment włożenia rąk warto wspomnieć, że w liturgiach wschodnich obrzędy namaszczenie prezentują ogromne bogactwo celebracyjne i w normalnej sytuacji (dziś niemal niespotykanej) powinny być sprawowane przez kilku prezbiterów (w zależności od tradycji: siedmiu lub pięciu). Warto również zauważyć, że praktyka duszpasterska związana $\mathrm{z}$ ministerium tegoż sakramentu różni się w poszczególnych Kościołach, a czasem nawet w ramach jednej i tej samej tradycji ${ }^{37}$.

W Kościołach tradycji zachodniosyryjskiej przewidziano kilka części obrzędu wraz z pięcioma seriami czytań biblijnych. Po każdej kolejnej serii kapłan wkłada ręce na głowę chorego odmawiając modlitwę, której słowa nawiązują do apostolskiego mandatu wkładania rąk. W modlitwie zawarta jest wyraźna aluzja do skutków sakramentu, jakimi są pokuta, odpuszczenie grzechów i uzdrowienie. Bezpośrednio po obrzędzie włożenia rąk w kolejnych sekwencjach następują namaszczenia poszczególnych części ciała chorego. Po zakończeniu piątej serii na głowę chorego wkłada się księgę Ewangelii. Podczas gdy celebrans główny trzyma otwarty ewangeliarz, pozostali koncelebransi wkładają ręce na głowę chorego, który w tym czasie trzyma w prawej ręce krzyż, będący być może z jednej strony znakiem wyznania wiary, zaś z drugiej symbolem przylgnięcia i zjednoczenia chorego z cierpiącym Chrystusem ${ }^{38}$.

Podobnie rzecz ma się w Kościołach tradycji bizantyjskiej, gdzie nałożenie rąk związane jest również z liturgią słowa i obrzędem namaszczenia. Obrzędy przewidują sześć serii czytań wraz z ekteniami błagalnymi. Po każdej z nich udzielający namaszczenia kapłan kładzie na głowie chorego otwarty ewangeliarz, po czym odmawia modlitwę i namaszcza w formie krzyża czoło, nozdrza, policzki, podbródek, pierś, ręce oraz dłonie chorego. Po tym obrzędzie następuje kolejna modlitwa oraz włożenie rąk. Celebrans główny nakłada na głowę chorego otwarty

${ }^{36}$ B. Nadolski (oprac.), Leksykon liturgii, s. 1005.

37 Zob. S. Rosso, La celebrazione, s. 411.

${ }^{38}$ M.R. Potoczny, Namaszczenie chorych w liturgiach Kościołów tradycji bizantyjskiej i łacińskiej, „Liturgia Sacra” 22 (2016) nr 2, s. 397. S. Rosso, La celebrazione, s. 227, 233-245. 
ewangeliarz i odmawia modlitwę prośby o odpuszczenie grzechów, pozostali prezbiterzy wyciągają nad nim ręce ${ }^{39}$.

\subsection{SAKRAMENT POKUTY I POJEDNANIA}

Kolejnym sakramentem jakiemu w Kościołach wschodnich towarzyszy nałożenie rąk jest sakrament pokuty i pojednania. W Kościołach syryjskich obrzęd nazywa się husāyā co oznacza pojednanie lub przebaczenie grzechów. W przypadku tradycji syro-orientalnej nie spotykamy gotowego rytuału pojednania, tym niemniej czasami zastosowanie ma obrzęd pojednania przeznaczony dla apostatów bądź heretyków, do którego sięga się również $\mathrm{w}$ przypadku pojednania grzeszników publicznych. Warto zauważyć, że włożenie rąk jest tu połączone $\mathrm{z}$ modlitwą o przebaczenie grzechów ${ }^{40}$. Ten sam gest spotykamy również w ukształtowanym obrzędzie pojednania tradycji zachodniosyryjskiej. Ciekawostką jest tu fakt, że gest nałożenia rąk ponawia się tu po wypełnieniu nałożonej pokuty. Penitent zobowiązany jest do ponownego stawienia się przed spowiednikiem, który nakładając na niego ręce tchnie trzykrotnie w jego twarz i odmawia modlitwę o charakterze błagalnym, po której penitent ponownie może przystępować do świętych misteriów ${ }^{41}$.

Jeśli chodzi o Kościoły tradycji bizantyjskiej to praktyka nie jest tu jednorodna. Niektórzy pisarze, np. słynny reformator liturgii konstantynopolitańskiej Teodor Studyta (†826), mówią o włożeniu ręki na głowę penitenta ${ }^{42}$. We współczesnym greckim euchologionie spotykamy gest nałożenia ręki, jednak nie bezpośrednio na głowę penitenta: spowiednik najpierw wkłada na jego głowę epitrachilion i dopiero wówczas kładzie na nim prawą rękę wypowiadając słowa rozgrzeszenia. Natomiast większość

39 M.R. Potoczny, Namaszczenie, s. 395-396. Por. N. Bux, M. Loconsole, I misteri, s. 74-80.

${ }^{40}$ I.-H. Dalmais, Le liturgie orientali, s. 125.

${ }^{41}$ Por. N. Bux, Riconciliazione in Oriente, w: Scientia Liturgica, t. 4, Sacramenti e sacramentali, red. A. J. Chupungco, Casale Monferrato 1998, s. 130-131.

${ }^{42}$ Zob. S. Parenti, Confessione, penitenza e perdono nelle chiese orientali, "Rivista Liturgica" 104/4 (2017), s. 127. 
trebników słowiańskich zawiera jedynie wskazania odnośnie do nałożenia epitrachilionu, nie wspominając nic o nakładaniu ręki ${ }^{43}$.

Swoistą ciekawostkę odnajdujemy w niektórych bizantyjskich wspólnotach monastycznych późnej starożytności. Jest tam mowa o geście włożenia ręki, którego dokonywał penitent względem spowiednika, kładąc mu rękę na szyi bądź obejmując go (sic!). Symbolicznie miało to wyrażać przeniesienie grzechów i uwolnienie od nich pokutnika ${ }^{44}$. Dziś jednak w żadnej wspólnocie podobnego gestu nie spotykamy.

\section{WNIOSKI}

Sakramenty należą do najświętszego i najcenniejszego depozytu, jaki posiada Kościół Jezusa Chrystusa. Nie dziwi więc fakt, że w wypełnianie sakramentalnej posługi wszystkie wspólnoty chrześcijańskie zaprzęgły nie tylko najpiękniejsze teksty i dzieła architektury, ale także symboliczne gesty, które wyrażają sens i działanie poszczególnych misteriów Kościoła. Bez wątpienia jednym $\mathrm{z}$ najistotniejszych gestów sakramentalnych jest gest nałożenia rąk, który niesie ze sobą głęboką symbolikę teologiczną.

Chociaż przywołane w pierwszej części niniejszego studium terminy chirotonía i chirothesía w sensie ścisłym odnoszą się do sakramentu święceń, to jednak w sensie szerszym możemy odnieść je również do innych sakramentalnych form nałożenia rąk. I tak, poza kontekstem posług, chirotonía możemy nazwać każde nałożenie rąk, które wiąże się z łaską udzielenia szczególnego daru Ducha Świętego (np. w misterium chrzcielnym czy w bierzmowaniu), zaś chirothesía to nałożenie rąk, które ma na celu umocnienie czy pocieszenie (np. w sakramencie chorych).

Idąc dalej tym tokiem rozumowania moglibyśmy wyróżnić jeszcze jedną ważną chirotonię sakramentalną, która nie dotyczy osób, a darów chleba i wina. Wszak w epiklezie eucharystycznej również chodzi o dar Ducha Świętego, zaś gestem jego przywołania jest wyciągnięcie kapłańskich rąk nad darami ofiarnymi. Chociaż w powyższym studium nie

${ }^{43}$ Zob. S. Rosso, La celebrazione, s. 360-362; por. A. Lorgus, M. Dudko, Orthodoxes Glaubensbuch, Würzburg 2001, s. 110.

${ }^{44}$ Zob. S. Parenti, Confessione, s. 126. 
zajmowaliśmy się tą kwestią, wydaję się słusznym zwrócić uwagę także na ten niezwykle ważny gest sakramentalny, który w różnych wspólnotach Wschodu również przyjmuje ciekawe formy (np. imitacja gołębich skrzydeł w tradycjach syryjskich).

Chociaż w niniejszym studium staraliśmy się przybliżyć ideę i praktykę gestu nałożenia rąk w celebracjach sakramentalnych Wschodu, wydaje się, że ta problematyka wciąż pozostaje niedoceniona i zbyt mało opracowana. Należy sobie życzyć, aby gest nałożenia rąk zyskiwał coraz głębszą podbudowę teologiczną, by nigdy nie utracił swego znaczenia i płynącej zeń dla wszystkich chrześcijan symboliki.

\section{BIBLIOGRAFIA}

Brock S.P., The Holy Spirit in the Syrian Baptismal Tradition, Piscataway 2008.

Bux N., M. Loconsole, I misteri degli Orientali, Siena 2006.

Bux N., Riconciliazione in Oriente, w: Scientia Liturgica, t. 4, Sacramenti e sacramentali, red. A.J. Chupungco, Casale Monferrato 1998, s. 127-142.

Cabié R., Liniziazione Cristiana, w: La Chiesa in preghiera, t. 3, I Sacramenti, red. A. Martimort, Brescia 2002, s. 25-120.

Caldecott S., Divine Touch: The Laying on Hands, "Communio" 38 (2011), s. 421-433.

Cozma I., The Holy Sacrament of Ordination - Principles and Elements of Canonical Doctrine, http://fto.ro/altarul-reintregirii/wp-content/uploads/2018/07/2.-Ioan-Cozma-33-55.pdf (dostęp: 20.10.2018).

Dalmais I.-H., Le liturgie orientali, Roma 1982.

Diekmann G., The Laying On of Hands: the Basic Sacramental Rite, "CTSA Proceeding" 29 (1974), s. 339-351.

George K.M., Sacrament of Ordination in the Malankara Orthodox-Syrian Church, w: Syriac Dialogue. Sixth Non-Official Consultation on Dialogue within the Syriac Tradition, red. P. Hofrichter, G. Wilflinger, Pro Oriente 6, Vienna 2004, s. 80-116.

Isho'yahb III, Liber Epistularum, CSCOSyr 64, Parisiis 1904.

Jounel P., Le ordinazioni, w: La Chiesa in preghiera, t. 3, I Sacramenti, red. A. Martimort, Brescia 2002, s. 159-201.

L'Eucologio Barberini gr. 336, red. S. Parenti, E. Velkovska, Roma $2000^{2}$.

Lorgus A., M. Dudko, Orthodoxes Glaubensbuch, Würzburg 2001.

Mannooramparampil T., Holy Orders and Priesthood in the Syro-Malabar Church, w: Syriac Dialogue. Sixth Non-Official Consultation on Dialogue within the Syriac Tradition, red. P. Hofrichter, G. Wilflinger, Pro Oriente 6, Vienna 2004, s. 117-155.

Nadolski B. (oprac.), Leksykon liturgii, Poznań 2006, s. 1005-1006.

Nadolski B., Leksykon symboli liturgicznych, Kraków 2012. 
Nin M., La liturgia dell'Ordine nella tradizione Siro-Occidentale (dispense per gli studenti), Roma 2012.

Nowakowski P., Liturgiczna eklezjologia sakramentu kapłaństwa w obrządku wschodnim, RBL 63 (2010) nr 2, s. 127-145 (DOI: https://doi.org/10.21906/rbl.166).

Parenti S., Confessione, penitenza e perdono nelle chiese orientali, "Rivista Liturgica" 104/4 (2017), s. 111-141.

Pomazansky M., Orthodox Dogmatic Theology, Platina 1984.

Potoczny M.R., Misterium chrzcielne w Asyryjskim Kościele Wschodu, Opole 2019.

Potoczny M.R., Namaszczenie chorych w liturgiach Kościołów tradycji bizantyjskiej i łacińskiej, „Liturgia Sacra” 22 (2016) nr 2, s. 385-401.

Potoczny M.R., Święcenia prezbiteratu w Kościołach syryjskich. Historia i struktura obrzędu, „Roczniki Teologiczne” 65 (2018) nr 8, s. 125-140 (DOI: http://dx.doi. org/10.18290/rt.2018.65.8-9).

Ridouard A., Ramię i ręka, w: Stownik teologii biblijnej, red. X. Leon-Dufour (red.), Poznań-Warszawa 1973, s. 852-853.

Romizi R., Vocabolario greco-italiano etimologico e ragionato, Bologna 2012.

Rosso S., La celebrazione della storia della salvezza nel rito bizantino. Misteri sacramentali, feste e tempi liturgici, Città del Vaticano 2010.

The Didascalia Apostolorum in Syriac, t. I, red. A. Vööbus, (CSCO 401, Syr. 175), Louvain 1979

The Order of Baptism, Urmi 1890.

Wojciechowski M., Język gestów w Starym Testamencie, RBL 41 (1988) nr 6, s. 504-517 (DOI: http://dx.doi.org/10.21906/rbl.2012). 